University of Nebraska - Lincoln

DigitalCommons@University of Nebraska - Lincoln

\title{
Efficiency and establishment of three introduced parasitoids of the mealybug Paracoccus marginatus (Hemiptera: Pseudococcidae)
}

\author{
Kaushalya G. Amarasekare \\ Oregon State University \\ Catharine M. Mannion \\ University of Florida \\ Nancy D. Epsky \\ USDA-ARS
}

Follow this and additional works at: https://digitalcommons.unl.edu/usdaarsfacpub

Part of the Agricultural Science Commons

Amarasekare, Kaushalya G.; Mannion, Catharine M.; and Epsky, Nancy D., "Efficiency and establishment of three introduced parasitoids of the mealybug Paracoccus marginatus (Hemiptera: Pseudococcidae)" (2009). Publications from USDA-ARS / UNL Faculty. 328.

https://digitalcommons.unl.edu/usdaarsfacpub/328

This Article is brought to you for free and open access by the U.S. Department of Agriculture: Agricultural Research Service, Lincoln, Nebraska at DigitalCommons@University of Nebraska - Lincoln. It has been accepted for inclusion in Publications from USDA-ARS / UNL Faculty by an authorized administrator of DigitalCommons@University of Nebraska - Lincoln. 


\title{
Efficiency and establishment of three introduced parasitoids of the mealybug Paracoccus marginatus (Hemiptera: Pseudococcidae)
}

\author{
Kaushalya G. Amarasekare ${ }^{\mathrm{a}, *}$, Catharine M. Mannion ${ }^{\mathrm{b}}$, Nancy D. Epsky ${ }^{\mathrm{c}}$ \\ a Oregon State University, Mid-Columbia Agricultural Research and Extension Center, 3005 Experiment Station Drive, Hood River, OR 97031, USA \\ ${ }^{\mathrm{b}}$ University of Florida, Institute of Food and Agricultural Sciences, Tropical Research and Education Center, 18905 SW 280 th Street, Homestead, FL 33031, USA \\ ' USDA-ARS Subtropical Horticulture Research Station, 13601 Old Cutler Road, Miami, FL 33158, USA
}

\section{A R T I C L E I N F O}

\section{Article history:}

Received 4 December 2008

Accepted 6 July 2009

Available online 9 July 2009

\section{Keywords:}

Biological control

Parasitism

Parasitoids

\begin{abstract}
A B S T R A C T
Three introduced parasitoids Acerophagus papayae, Anagyrus loecki, and Pseudleptomastix mexicana of the mealybug Paracoccus marginatus have been released in Miami-Dade and Broward counties (Florida) in 2003. Efficiency and establishment of these previously introduced parasitoids to control P. marginatus were measured in 2005 and 2006, at three locations in Homestead (Miami-Dade). Mealybug populations were initially established on three branches (per plant) of 10 hibiscus plants inside closed-sleeve cages. The three treatments, closed, open, and no-cage environments were applied to the three established mealybug populations on each plant. The number of mealybugs and natural enemies was monitored in all treatments. After $72 \mathrm{~h}$, the number of $P$. marginatus in the open-sleeve cage was higher than in the no-cage treatment but both were lower than the number in the closed-sleeve cage. Efficiency of parasitoids was evaluated by their percentage parasitism. Percentage parasitism (=recovery) was also used as an indicator for parasitoid establishment. Two of the three previously released parasitoids (A. papayae and $A$. loecki) were recovered in this study. Acerophagus papayae had a higher percentage parasitism than $A$. loecki in both the open-sleeve cage (31.0\% vs $2.3 \%$ ) and the no-cage treatments ( $21.4 \%$ vs $1.6 \%$ ) and caused the most mortality of $P$. marginatus. There was no recovery of $P$. mexicana in either of the treatments. Although both A. papayae and A. loecki were established in tested areas, A. papayae was more efficient in controlling $P$. marginatus than A. loecki. The reasons for not recovering $P$. mexicana in release areas is yet unknown.
\end{abstract}

(c) 2009 Elsevier Inc. All rights reserved.

\section{Introduction}

The mealybug Paracoccus marginatus Williams and Granara de Willink is a polyphagous pest insect that can damage a large number of tropical and sub-tropical fruits, vegetables, and ornamental plants, including Carica papaya L. (papaya), Hibiscus spp. (hibiscus), Citrus spp. (citrus), Persea americana Mill. (avocado), and Solanum melongena L. (eggplant) (Miller and Miller, 2002). Believed to be native to Mexico or Central America, P. marginatus has been established in the Caribbean since 1994 (Miller et al., 1999). In 1998, P. marginatus was first detected in the United States in Manatee, Palm Beach, and Broward counties in Florida (Miller et al., 1999). In recent years, $P$. marginatus has invaded the Pacific islands, and it is now established in Guam (Meyerdirk et al., 2004), the Republic of Palau (Muniappan et al., 2006), and Hawaiian islands (Heu et al., 2007).

Paracoccus marginatus potentially poses a threat to numerous agricultural products in the United States especially in Florida

\footnotetext{
* Corresponding author. Fax: +1 5413861905.

E-mail address: kaushalya2641@yahoo.com (K.G. Amarasekare).
}

and states such as California, Hawaii, and Texas, which produce similar crops. Classical biological control was identified as an important component in the management of $P$. marginatus (Walker et al., 2006) and currently, there are three solitary-endoparasitoids mass-reared in Puerto Rico, and released in P. marginatus infested areas in the Caribbean, the United States, and Pacific islands (Meyerdirk et al., 2004). They are Acerophagus papayae Noyes and Schauff, Anagyrus loecki Noyes and Menezes, and Pseudleptomastix mexicana Noyes and Schauff (Hymenoptera: Encyrtidae) (Noyes and Schauff, 2003).

Acerophagus papayae and A. loecki were released with two other parasitoids (Anagyrus californicus Compere and Pseudaphycus sp.) in Bradenton (Manatee County), Florida in 2000 (Ngyuen, 2000) but the outcome of releases of these parasitoids is yet to be determined (Walker et al., 2006). Acerophagus papayae, A. loecki, and $P$. mexicana have been released in Miami-Dade and Broward counties (Florida) for the first time in 2003 (Meyerdirk, 2003; Amalin, unpublished). Although it is believed that these three parasitoids are established in the release areas, information on their establishment and effectiveness is limited in the United States. Assessing the effect of a natural enemy or natural enemy complex on its/their 
host populations in the field is important to evaluate the success of a biological control project (Neuenschwander et al., 1986). In this study, the efficiency and establishment of three previously released parasitoids (A. papayae, A. loecki, and P. mexicana) of P. marginatus in Miami-Dade County was assessed in the field.

\section{Materials and methods}

\subsection{Insect rearing}

A colony of $P$. marginatus was maintained on red potatoes (sprouted) (Solanum tuberosum L.) (Ryan Potato Company, East Grand Forks, MN) in an environmental growth chamber (Percival I-36LL, Percivel Scientific Inc., Perry, NC) set at $25^{\circ} \pm 1{ }^{\circ} \mathrm{C}, 65 \pm 2 \%$ R.H., and 14:10 (L:D) photoperiod. Initially, P. marginatus was collected from a papaya (C. papaya L.) field in Homestead, FL. Each week, 35 sprouted potatoes were infested with $P$. marginatus ovisacs (each potato with 3-5 ovisacs) collected from the previously infested potatoes selected from the colony to maintain the mealybug population. Sprouted potatoes were infested for 8 weeks before they were used in the experiment. Rearing methods were similar to methods used by Amarasekare et al., 2008.

\subsection{Field experiments}

Research plots were selected in three homeowner landscape locations in Homestead (Miami-Dade) and the experiments were carried out in July to August 2005 and 2006, using the same experimental locations. Paracoccus marginatus was observed in all three locations at the time of selection. In each location, 10 hibiscus (Hibiscus rosasinensis L.) plants, approximately 2.5-3.0 m tall, were selected. Each plant was considered a replicate. The three treatments used in this experiment were closed-sleeve cage, opensleeve cage, and no-cage. The sleeve cages were made of white chiffon cloth material (Jo-Ann Fabrics and Crafts, Miami, FL), $72 \mathrm{~cm}$ in length and $50 \mathrm{~cm}$ in width. Along the length of the material, a groove was sewn at $15 \mathrm{~cm}$ from each end. The piece of cloth with the grooves was then folded in half along the width, and the two ends along the width were placed together and sewn at the edge to make a cylinder of $15 \mathrm{~cm}$ diameter. A piece of stainless steel (20 gauge) wire (Tower Manufacturing Company, Madison, IN), $72 \mathrm{~cm}$ in length was inserted through each groove and tied at the ends to make a ring to shape the cage into a cylindrical cage. Three branches 1-1.5 $\mathrm{m}$ above ground were selected from each hibiscus plant. The branches selected were evenly distributed among the hibiscus plants, and each branch had 7-10 leaves. All the selected branches were cleaned with moist tissues (Kimwipes ${ }^{\circledR}$ EX-L, Kimberly-Clerk Global Sales Inc., Roswell, GA) to make them free from any insects and eggs and were enclosed in a closedsleeve cage to observe for any insect presence or development. To avoid the cloth material of the cage getting in contact with the leaves, a stainless steel wire (22 gauge and $25 \mathrm{~cm}$ in length) was tied to the branch at the middle at each end of the cage, and the ends were fixed to the cage along the diameter. Sleeves of the cage were secured with a stainless steel wire tied around the enclosed branch. All enclosed branches were checked daily for 7 days for the presence of any insects by opening the sleeve at the terminal end of the branch of each cage. If any insects were observed in a cage, the branch was cleaned again using the above procedure.

After 7 days, the caged section of each branch was artificially infested with $P$. marginatus by placing five gravid colony females (each from different infested potato and $\sim 30-35 \mathrm{~d}$ old) on the terminal leaves of the branch within the cage using a (No. 000) paint brush (American Painter 4000, Loew-Cornell Inc., Englewood Cliffs,
$\mathrm{NJ}$ ). When the number of second and third instars (from the eggs laid by the infested gravid females) was at $\sim 1: 1$ ratio by visual inspection (after $\sim 21 \mathrm{~d}$ ), the experiment was initiated. Sleeve cages were removed from one branch per plant for the no-cage treatment. Sleeve cages from a second branch were opened and the sleeves were folded back along the cylindrical part of the cage and were fixed to the cage with four safety pins for the open-sleeve cage treatment. Sleeve cages remained closed on the third branch for the closed-sleeve cage treatments. Assignment of the three treatments per tree was random. All artificially-infested branches were checked for coccinellid predators, ants, and spiders after 24 , 48 , and $72 \mathrm{~h}$ without disturbing the cages. At $72 \mathrm{~h}$, sleeves were closed in open-sleeve cages and closed-sleeve cages were placed over all infested branches in no-cage treatment, and branches were removed from the plant and were brought back to the laboratory.

The number of mealybugs and the number of adults and larvae of the mealybug-destroyer (Cryptolaemus montrouzieri Mulsant) (coccinellid predator), ants, and spiders were recorded. From each replicate, 100 mealybugs (second and third author) were randomly collected, and were placed on sprouting potatoes for further development, and percentage parasitized determined. These potatoes were kept singly in $500 \mathrm{ml}$ deli cups (Georgia Pacific Dixie, Atlanta, GA). Each cup was covered with a piece of chiffon cloth held in a place with the cup lid with a circular area of $8.5 \mathrm{~cm}$ diameter removed to facilitate air circulation. The cups were held in an insectary, maintained at $25^{\circ} \pm 1{ }^{\circ} \mathrm{C}, 12: 12$ (L:D) photoperiod, and $65 \pm 2 \%$ R.H. Mealybugs were allowed to mummify on potatoes. Collection of mummified mealybugs was started 10 days after placing them on potatoes. Mummified mealybugs were placed individually in disposable, glass culture tubes $(1.2 \mathrm{~cm}$ diameter and $7.5 \mathrm{~cm}$ length) (Fisherbrand ${ }^{\circledR}$, Fisher Scientific, Pittsburgh, PA). Each tube was covered with two-ply tissue (Kimwipes ${ }^{\circledR}$ EXL, Kimberly-Clerk Global Sales Inc., Roswell, GA), secured with 2.5-cm-long piece of clear polyvinyl chloride (PVC) tubing (Fisherbrand $^{\circledR}$, Fisher Scientific, Pittsburgh, PA) until the emergence of parasitoids. The emerging parasitoids from the culture tubes were sexed and were identified to species. Samples of parasitoids, mealybug destroyers, and ants were sent to the Systematic Entomology Laboratory (SEL), USDA, Beltsville, MD for verification of identification. Samples of spiders were sent to Division of Plant Industry, Florida Department of Agriculture and Consumer Services, Gainesville, FL for species identification. Efficiency of parasitoids was evaluated by their percentage parasitism ([number of emerged parasitoids/100 mealybugs] $\times 100$ ). The percentage parasitism (=recovery) was also used as an indicator of parasitoid establishment.

\subsection{Statistical analysis}

The experimental design was completely random with 10 replicates at each location. A three-way analysis of variance (ANOVA) was performed using the general linear model (PROC GLM) (SAS Institute, 1999) to find the interaction among year, location, and treatment for mealybugs, mealybug destroyers, ants, spiders, and proportion of parasitism (of each parasitoid species).

Means of mealybugs were compared at $P=0.05$ significance level using the Tukey's HSD test. Only data from the open-sleeve cage and no-cage treatments were used for analysis of natural enemies since no natural enemies were recovered in the closed-sleeve cage treatments. A repeated measure ANOVA using PROC GLM was performed for adults and larvae of mealybug destroyers, spiders, and ants collected after 24,48 , and $72 \mathrm{~h}$ and means were compared using a $t$-test (PROC TTEST). Effect of treatment on percentage parasitism within each parasitoid species, and effect of parasitoid species within each treatment were tested using a two-way ANOVA 
and means were compared at $P=0.05$ significance level using least square means (LSMEANS) of SAS (SAS Institute, 1999).

Percentage parasitism of $A$. papayae and $A$. loecki for both opensleeve cage and no-cage treatments were arcin square-root transformed using,

$p^{\prime}=\arcsin \sqrt{p}$

where, $p=$ percentage parasitism, to adjust the variances (Zar, 1984) before ANOVA.

\subsection{Voucher specimens}

Voucher specimens of mealybugs, mealybug-destroyer adults and larvae, ants, spiders, and parasitoids were deposited in the Entomology and Nematology Department insect collection, at the Tropical Research and Education Center, University of Florida, Homestead, FL.

\section{Results}

There was no interaction in the mean proportion of parasitoids emerged from the mealybug samples collected by treatment, location, and year for $A$. papayae $(F=0.86, \mathrm{df}=2,108, P=0.4260)$, and A. loecki $(F=0.23, \mathrm{df}=2,108, P=0.7919)$. Therefore, the data were pooled by treatment, location, and year and pooled data were used in the analyses. Acerophagus papayae had higher percent parasitism in the open-sleeve cage than in the no-cage treatment by $30.9 \%$ (Table 1). Within a treatment, $A$. papayae had a higher parasitism than $A$. loecki by $92.6 \%$ in the open-sleeve cage and by $92.5 \%$ in the no-cage treatment, respectively. Percent parasitism of $A$. loecki in the open-sleeve cage was $30.8 \%$ higher than in the no-cage treatment (Table 3). The open-sleeve cage had 30.9\% higher cumulative

Table 1

Individual and cumulative mean percentage parasitism ( \pm SEM) of $P$. marginatus by $A$. papayae, $A$. loecki, and $P$. mexicana ${ }^{*}$, in open-sleeve cage, and no-cage treatments using pooled data of 2005 and 2006 in three experimental locations.

\begin{tabular}{llll}
\hline & Parasitism $(\%)$ & \\
\cline { 2 - 4 } Treatment & A. papayae & A. loecki & Cumulative \\
\hline Open-sleeve cage & $31.0 \pm 0.3 \mathrm{aA}$ & $2.3 \pm 0.1 \mathrm{aB}$ & $33.3 \pm 0.3 \mathrm{a}$ \\
No-cage & $21.4 \pm 0.3 \mathrm{bA}$ & $1.6 \pm 0.1 \mathrm{bB}$ & $23.0 \pm 0.3 \mathrm{~b}$ \\
Source & $F$ & $\mathrm{df}$ & $P$ \\
Model & 3606.07 & 5354 & $<0.0001$ \\
Parasitism & 8038.27 & 2354 & $<0.0001$ \\
Treatment & 1387.10 & 1354 & $<0.0001$ \\
Parasitism $*$ treatment & 283.36 & 2354 & $<0.0001$ \\
\hline
\end{tabular}

$n=60$.

Means within a column followed by the same lowercase letters and means within a row followed by the same uppercase letters are not significantly different at $\alpha=0.05$ (least square means (LSMEANS) test)

No parasitism was recorded for $P$. mexicana. percent parasitism than the no-cage treatment. Both $A$. papayae and $A$. loecki had 1:1 (male:female) sex ratio. No parasitism by $P$. mexicana was observed in this study.

There was no interaction among the effect of location, year, and treatment on the number of $P$. marginatus collected from each treatment $(F=0.12, \mathrm{df}=4,162, P=0.9737)$. Therefore, the data were pooled by location, year, and treatment, and the effect of treatment was analyzed by a one-way ANOVA. The mean $( \pm S D)$ number of $P$. marginatus collected from the closed-sleeve cage $(410.9 \pm 1.6)$ was higher than the numbers collected from the open-sleeve cage $(171.6 \pm 1.3)$ and the no-cage treatment $(109.1 \pm 0.7)$ by $58.2 \%$ and $73.4 \%$, respectively, $(F=16800.4$, $\mathrm{df}=2,177, P<0.0001)$.

Natural enemies such as mealybug-destroyer adults and larvae, and spiders were observed at all three locations. There was no interaction in the mean number of individuals collected by location, year, and treatment for mealybug-destroyer adults $(F=0.01$, $\mathrm{df}=2, \quad 346, \quad P=0.9998)$ and larvae $(F=0.04, \quad \mathrm{df}=2, \quad 346$, $P=0.9599)$, ants $(F=0.04, \mathrm{df}=2,346, P=0.9653)$, and spiders $(F=0.14, \mathrm{df}=2,346, P=0.8733)$. Therefore, the pooled data for each of these insects were used in the analyses. The repeated measures ANOVA for within subject effects showed that there was no interaction between the interval and the treatment $(F=0.01$, $\mathrm{df}=2,944, P=0.9931)$. There were more mealybug-destroyer adults and larvae (Table 2), ants, and spiders (Table 3 ) in the nocage than in the open-sleeve cage treatment at 24,48 , and $72-h$ intervals.

The spiders collected from the treatments were composed of Gasteracantha cancriformis (Linnaeus), Cyclosa walckenaeri (O.P. Cambridge) (Araneae: Araneidae), Lyssomanes viridis (Walckenaer) (Araneae: Salticidae), Misumenops sp. (Araneae: Thomisidae), Hibana sp. (Araneae: Anyphaenidae), Theridion melanostictum O.P. Cambridge (Araneae: Theridiidae), and Leucauge sp. (Araneae: Tetragnathidae). None of the species of spiders collected was dominant in any of the treatments. The ants collected from the treatments were composed of Tapinoma sessile Say, Pheidole sp., and Technomyrmex sp. (Hymenoptera: Formicidae). Tapinoma sessile was the predominant ant species collected from the three locations in both 2005 and 2006, and is a common and widely distributed North American ant species (Smith, 1928).

\section{Discussion}

Two of the three parasitoids released in 2003 for the biological control of $P$. marginatus in Miami-Dade and Broward counties were recovered in this study. Acerophagus papayae is well established and efficient in controlling $P$. marginatus. Although established in the field, efficiency of $A$. loecki was lower than A. papayae. Pseudleptomastix mexicana was not recovered in this study; hence, its efficiency could not be evaluated. Not recovering $P$. mexicana from

Table 2

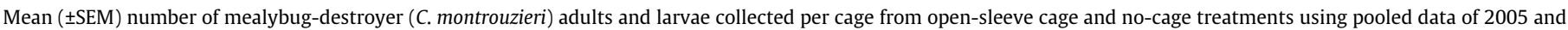
2006 in three experimental locations.

\begin{tabular}{|c|c|c|c|c|c|c|}
\hline & \multicolumn{3}{|c|}{ Mealybug destroyer (adult) per cage } & \multicolumn{3}{|c|}{ Mealybug destroyer (larva) per cage } \\
\hline & \multicolumn{3}{|c|}{ Interval (h) } & \multicolumn{3}{|c|}{ Interval (h) } \\
\hline & 24 & 48 & 72 & 24 & 48 & 72 \\
\hline Open-sleeve cage & $2.0 \pm 0.1$ & $2.1 \pm 0.1$ & $2.1 \pm 0.1$ & $1.2 \pm 0.1$ & $1.1 \pm 0.1$ & $1.3 \pm 0.1$ \\
\hline No-cage & $3.0 \pm 0.1$ & $3.0 \pm 0.1$ & $3.1 \pm 0.1$ & $2.1 \pm 0.1$ & $2.1 \pm 0.1$ & $2.1 \pm 0.1$ \\
\hline$t$ & -7.33 & -6.79 & -6.86 & -8.42 & -8.21 & -8.42 \\
\hline df & 118 & 118 & 118 & 118 & 118 & 118 \\
\hline$P$ & $<0.0001$ & $<0.0001$ & $<0.0001$ & $<0.0001$ & $<0.0001$ & $<0.0001$ \\
\hline
\end{tabular}


Table 3

Mean $( \pm$ SEM) number of ants and spiders collected from open-sleeve cage and no-cage treatments using pooled data of 2005 and 2006 in three experimental locations.

\begin{tabular}{|c|c|c|c|c|c|c|}
\hline & \multicolumn{3}{|l|}{ Ants } & \multicolumn{3}{|l|}{ Spiders } \\
\hline & \multicolumn{3}{|c|}{ Interval (h) } & \multicolumn{3}{|c|}{ Interval (h) } \\
\hline & 24 & 48 & 72 & 24 & 48 & 72 \\
\hline Open-sleeve cage & $21.4 \pm 0.2$ & $21.3 \pm 0.2$ & $21.5 \pm 0.2$ & $2.0 \pm 0.1$ & $2.1 \pm 0.1$ & $2.1 \pm 0.1$ \\
\hline No-cage & $30.9 \pm 0.3$ & $30.9 \pm 0.2$ & $31.0 \pm 0.2$ & $2.9 \pm 0.1$ & $3.1 \pm 0.1$ & $3.0 \pm 0.1$ \\
\hline$t$ & -27.32 & -30.52 & -29.93 & -6.88 & -7.77 & -7.06 \\
\hline df & 118 & 118 & 118 & 118 & 118 & 118 \\
\hline$P$ & $<0.0001$ & $<0.0001$ & $<0.0001$ & $<0.0001$ & $<0.0001$ & $<0.0001$ \\
\hline
\end{tabular}

$n=60$.

experimental locations also raised the question of its ability to establish in released areas.

Other than P. marginatus, no other hosts have been recorded for Acerophagus papayae (Noyes and Schauff, 2003). Anagyrus loecki is not a host-specific classical biological control agent (Noyes, 2000). In addition to being a parasitoid of $P$. marginatus, $A$. loecki can develop in Dysmicoccus hurdi McKenzie and Phenacoccus madeirensis Green (Hemiptera: Pseudococcidae) (Noyes, 2000) and P. madeirensis is one of the common mealybug species found in Florida (Williams and Granara de Willink, 1992; Ben-Dov, 1994). The low parasitism by $A$. loecki in both open-sleeve cage and no-cage treatments may be due to its multiple host preference. No other hosts have been recorded for P. mexicana (Noyes and Schauff, 2003).

Not recovering any $P$. mexicana from the collected $P$. marginatus raises an interesting question of whether $P$. mexicana successfully established in the release areas. In July 2003, 1400 A. papayae, 1200 A. loecki and 3400 P. mexicana were released in Miami-Dade and Broward counties, Florida, as a one-time release in 21 locations (Amalin, unpublished). Out of these 21 locations, five were in Homestead (Miami-Dade) where these field studies were conducted. Although the number of $A$. papayae or $A$. loecki released was less than half the number of released P. mexicana, both $A$. papayae and $A$. loecki were recovered from the field. Even after several releases, $P$. mexicana has not been recovered in field assessment studies conducted in the Republic of Palau (Muniappan et al., 2006). A similar study was conducted in Guam in 2002, although the results were reported without the recovery data of parasitoids (Meyerdirk et al., 2004). There is very little information on $P$. mexicana, and there is no information on why it was not recovered from the field in previous studies. One of the reasons for not recovering any hyper-parasitoids from this study may be due to the short duration $(72 \mathrm{~h})$ of mealybugs' exposure to parasitoids.

Sympatric parasitoid species that share the same host species may be competitors (Van Strien-van Liempt, 1983). The greater the part of the host population that is exploited by both species, the more they will affect each other's population density. Their competitive abilities then, among other factors, determine their relative abundance (Van Strien-van Liempt, 1983). According to Dent (1995), when two species compete with one another intensely enough over limited resources, then with time, one or the other can become extinct. When there is a dominant parasitoid, which can displace other parasitoid species, the releasing of several species might not provide the expected efficiency of a biological control program (Dent, 1995). Not recovering P. mexicana could be due to either it was not established from the initial release or it was displaced by A. papayae. Having other host mealybug species for $A$. loecki may have helped it to establish.

Developmental time, longevity, and lifetime fertility are important fitness parameters when evaluating the efficiency of a parasitoid as a biological control agent and understanding its long-term effects in a system (Hemerik and Harvey, 1999). These fitness parameters are also important when evaluating several parasitoid species that have been released in a classical biological control program to manage a single host. Laboratory experiments conducted to find the life history and interspecific competition of these three parasitoids showed a longer life cycle for $P$. mexicana than for $A$. papayae or $A$. loecki and superior competitive ability of $A$. papayae over other two species in early instar mealybugs (Amarasekare, unpublished). This information, which is currently being prepared as manuscripts will help to explain the differences of these three parasitoids in their efficiency and establishment.

One of the principal obstacles of host evaluation is the difficulty of excluding the natural enemies from the host population (Smith and DeBach, 1942). In this study, sleeve cages were used as a physical exclusion method to investigate effect of natural enemies on the host population. Limitations and applicability of physical exclusion methods on different natural enemies have been evaluated (Kiritani and Dempster, 1973; Van Lenteren, 1980). One limitation of this method is that it may cause conditions within the sleeve cage to depart too far from the normal conditions outside the sleeve cage (Smith and DeBach, 1942). The closed-sleeve cage protected the mealybugs from natural enemies as well as from environmental factors such as the rain and the wind, while the open-sleeve cage provided some protection and the no-cage treatment provided no protection from the adverse environmental conditions. The greater host population in the closed environment shows that when there was no outside interference from natural enemies and no direct impact of the wind and rain, insects survive better than in the open environment where they are more exposed to direct environmental factors as well as their natural enemies. Similar results have been reported for Rastrococcus invadens Williams (Boavida et al., 1995).

The presence of predators such as $C$. montrouzieri adults and larvae, and spiders may have a negative effect on percent parasitism. Cryptolaemus montrouzieri was also collected in relatively low numbers in field assessment studies of the parasitoids of $P$. marginatus, conducted in the Republic of Palau (Muniappan et al., 2006) and in Guam (Meyerdirk et al., 2004). There is a possibility that parasitized mealybugs were preyed on by $C$. montrouzieri. Most coccinellid predators feed on more than one prey species; thus, disruption of existing biological control by introduced coccinellids and the potential for indigenous coccinellid species to disrupt introductions can happen (Rosenheim et al., 1995). Common forms of intraguild predation include predators that attack herbivores that harbor a developing parasitoid (Rosenheim et al., 1995). This may be one reason that higher parasitism was observed in the open-sleeve cage treatment than in the no-cage treatment, because there were more predators in the no-cage treatment, and $P$. marginatus was directly exposed to the environment.

Higher numbers of ants present in the no-cage treatment may have affected the foraging behavior of parasitoids. This may be one of the reasons for lower cumulative parasitism in the no-cage treatment compared to the open-sleeve cage treatment. Generally, mealybugs and ants have mutualistic relationships. Mealybugs 
benefit from ant association when ants promote sanitation in mealybug populations and/or protect mealybugs from natural enemies (Gonzales-Hernandez et al., 1999). It has been repeatedly observed that some pests have higher population densities on plants where ants are active than on plants free of ants (Hodek et al., 1972). There is considerable direct evidence of aggressive behavior toward predators or parasites in honeydew seeking ants. Pheidole megacephala (F.) significantly decreased Dysmicoccus brevipes (Cockerell) mortality, by Anagyrus ananatis Gahan and Nephus bilucernarius Mulsant (Coleoptera: Coccinellidae) adults via interference with natural enemy searching behavior (Gonzales-Hernandez et al., 1999). Presence of ants in both open-sleeve cage and nocage treatments may have some influence on the parasitism by $A$. papayae and $A$. loecki, although the effect of ants on mealybugs and parasitoids was not investigated in this study.

Out of the three currently used parasitoids of $P$. marginatus, $A$. papayae is well established in the field, and is the main contributor to the mortality of this mealybug species. Although it was recovered from $P$. marginatus and established in release areas, its multiple host preference may have caused the lower efficiency of $A$. loecki compared to A. papayae. There was no recovery of $P$. mexicana; hence, its efficiency could not be evaluated in this study.

\section{Acknowledgments}

This study was conducted in partial fulfillment of the requirement for a Ph.D. at the University of Florida, USA, by K.G. Amarasekare. We thank R. McSorley, L. Osborne, and H. Frank of University of Florida for reviewing an early draft of this paper and M. Brennan, of IFAS Statistics, University of Florida, for her help with the statistical analyses. We thank M. Buffington, (Formicidae), M.W. Gates (Encyrtidae) and N.J. Vandenberg (Coccinellidae) (Systematic Entomology Laboratory, USDA-ARS) and G.B. Edwards (Araneae), and G. Hodges (Pseudococcidae) (DPI, Florida Department of Agriculture and Consumer Services) for insect and spider identifications and M.S. Frank (Florida Museum of Natural History, University of Florida Herbarium) for plant identifications. We thank C. Glenn, B. Going, C. Towery, and the staff and the management of "The Palace", The Senior Living Facility of Homestead, FL for allowing their hibiscus plants be used in this study, and the USDA-ARS for funding for this experiment.

\section{References}

Amarasekare, K.G., Mannion, C.M., Osborne, L.S., Epsky, N.D., 2008. Life history of Paracoccus marginatus (Hemiptera: Pseudococcidae) on four host plant species under laboratory conditions. Environmental Entomology 37, 630-635.

Ben-Dov, Y., 1994. A Systematic Catalogue of the Mealybugs of the World. Intercept Hants, UK.

Boavida, C., Neuenschwander, P., Herren, P., 1995. Experimental assessment of the impact of the introduced parasitoid Gyranusoidea tebygi Noyes on the mango mealybug Rastrococcus invadens Williams, by physical exclusion. Biological Control 5, 99-103.

Dent, D., 1995. Principles of integrated pest management. In: Dent, D. (Ed.), Integrated Pest Management. Chapman and Hall, New York, NY, pp. 8-46.

Gonzales-Hernandez, H., Johnson, M.W., Reimer, N.J., 1999. Impact of Pheidole megacephala (F.) (Hymennoptera: Formicidae) on the biological control of
Dysmicoccus brevipes (Cockerell) (Homoptera: Pseudococcidae). Biological Control 15, 145-152.

Hemerik, L., Harvey, J.A., 1999. Flexible larval development and the timing of destructive feeding by a solitary endoparasitoid: an optimal foraging problem in evolutionary perspective. Ecological Entomology 24, 308-315.

Heu, R.A., Fukada, M.T., Conant, P., 2007. Papaya mealybug, Paracoccus marginatus Williams and Granara de Willink (Hemiptera: Pseudococcidae). New Pest Advisory. 4(3). Department of Agriculture, State of Hawaii, Honolulu, HI.

Hodek, I., Hagen, K.S., Van Emden, H.F., 1972. Methods for studying effectiveness of natural enemies. In: Van Emden, H.F. (Ed.), Aphid Technology. Academic Press, London, England, pp. 147-188.

Kiritani, K., Dempster, J.P., 1973. Different approaches to the quantitative evaluation of natural enemies. Journal of Applied Ecology 10, 323-329.

Meyerdirk, D.E., 2003. Control of papaya mealybug, Paracoccus marginatus (Hemiptera: Pseudococcidae). Environmental Assessment (Supplement). Center for Plant Health Science and Technology. National Biological Control Institute, PPQ APHIS, USDA, Riverdale, MD.

Meyerdirk, D.E., Muniappan, R., Warkentin, R., Bamba, J., Reddy, G.V.P., 2004. Biological control of the papaya mealybug, Paracoccus marginatus (Hemiptera: Pseudococcidae) in Guam. Plant Protection Quarterly 19 (3), 110-114.

Miller, D.R., Miller, G.L., 2002. Re-description of Paracoccus marginatus Williams and Granara de Willink (Hemiptera: Pseudococcidae) including descriptions of the immature stages and adult male. Proceedings of the Entomological Society of Washington 104, 1-23.

Miller, D.R., Williams, D.J., Hamon, A.B., 1999. Notes on a new mealybug (Hemiptera: Coccoidea: Pseudococcidae) pest in Florida and the Caribbean: the papaya mealybug, Paracoccus marginatus Williams and Granara de Willink Insecta Mundi 13 (3-4), 179-181.

Muniappan, R., Meyerdirk, D.E., Sengebau, F.M., Berringer, D.D., Reddy, G.V.P., 2006 Classical biological control of the papaya mealybug, Paracoccus marginatus (Hemiptera: Pseudococcidae) in the republic of Palau. Florida Entomologist 89, 212-217.

Neuenschwander, P., Schulthess, F., Madojemu, E., 1986. Experimental evaluation of the efficiency of Epidinocarsis lopezi, a parasitoid introduced into Africa against the cassava mealybug Phenacoccus manihoti. Entomologia Experimentalis et Applicata 42, 133-138.

Ngyuen, R., 2000. Crawford announces new biological control of plant pest. Department Press Release 10-10-2000. Division of Plant Industry, Florida Department of Agriculture and Consumer Services, Gainesville, FL.

Noyes, J.S., 2000. Encyrtidae of Costa Rica, I. The subfamily Tetracneminae (Hymenoptera: Chalcidoidea), parasitoids of mealybugs (Homoptera: Pseudococcidae). Memoirs of the American Entomological Institute 62, 101103.

Noyes, J.H., Schauff, M.E., 2003. New Encyrtidae (Hymenoptera) from papaya mealybug (Paracoccus marginatus Williams and Granara de Willink) (Hemiptera: Sternorrhyncha: Pseudococcidae). Proceedings of the Entomological Society of Washington 105, 180-185.

Rosenheim, J.A., Kaya, H.K., Ehler, L.E., Marois, J.J., Jaffee, B.A., 1995. Intraguild predation among biological-control agents: theory and evidence. Biological Control 5, 303-335.

SAS Institute, 1999. SAS User's Guide. Version 9.1. SAS Institute, Cary, NC.

Smith, H.S., DeBach, P., 1942. The measurement of the effect of entomophagous insects on population densities of the host. Journal of Economic Entomology 35 845-849.

Smith, M.R., 1928. The biology of Tapinoma sessile Say, an important house-infesting ant. Annals of Entomological Society of America 21, 307-330.

Van Lenteren, J.C., 1980. Evaluation of control capabilities of natural enemies. Does art have to become science? Netherlands Journal of Zoology 30, 369-381.

Van Strien-van Liempt, W.T.F.H., 1983. The competition between Asobara tabida Nees von Esenbeck, 1834 and Leptopilina heterotoma (Thomson, 1862) in multiparasitized hosts. Netherlands Journal of Zoology 33, 125-163.

Walker, A., Hoy, M., Meyerdirk, D., 2006. Papaya mealybug (Paracoccus marginatus Williams and Granara de Willink (Insecta: Hemiptera: Pseudococcidae)). EENY302. Featured Creatures. Entomology and Nematology Department, Florida Cooperative Extension Service, Institute of Food and agricultural Sciences, University of Florida, Gainesville, FL.

Williams, D.J., Granara de Willink, M.C., 1992. Mealybugs of Central and South America. CAB International, Wallinford, Oxon, England.

Zar, J.H., 1984. Biostatistical Analysis, second ed. Prentice Hall, Englewood Cliffs, NJ. 